\title{
EXTERNALITY OF MULTINATIONAL COMPANIES IN BONDED ZONE TO LOCAL COMPANY PRODUCTIVITY IN INDONESIA
}

\author{
Setiyono Nugroho ${ }^{1}$, Prani Sastiono ${ }^{2}$ \\ ${ }^{1}$ Program Pascasarjana Ilmu Ekonomi, Fakultas Ekonomi dan Bisnis, Universitas \\ Indonesia, Depok, 16424 \\ ${ }^{2}$ Program Pascasarjana Ilmu Ekonomi, Fakultas Ekonomi dan Bisnis, Universitas \\ Indonesia, Depok, 16424 \\ Email:setionugroho85@gmail.com
}

\begin{abstract}
ARTICLE INFORMATION
Received date

[08-05-2020]

Revision

[10-06-2020]

Accepted date

[22-06-2020]
\end{abstract}

\begin{abstract}
:
Multinational Companies (MNC) in the Bonded Zone (BZ) obtain tax incentives and are required to export their product. Those differences allegedly led to the difference in externalities. This paper discussed the indirect impact of MNC on the productivity of local firms in Indonesia with a measure of productivity using Total Factor Productivity (TFP). Furthermore, this thesis seeks to measure the difference impact between MNC which operated on BZ and MNC which operated outside the BZ. Using the tax report data period 2011-2015, the estimation result shows that the presence of MNC brings positive externalities to local firm productivity, and MNC which operated on BZ have bigger externalities than MNC which operated outside BZ.
\end{abstract}

Keywords: Externalities, Multinational Companies, Bonded Zone, Total Factor Productivity 


\section{INTRODUCTION}

The trade war between the US and China continues to this day with no signs of ending (picture 1). Because of the trade war, the US and China are trying to find markets to replace export destinations, one of which is Indonesia. This caused the depressed trade balance in Indonesia. During 2019 Indonesia's trade balance was a deficit of US \$ 2.55 billion (Indonesian Customs, January 2020). Pressure on the import and export sector also contributed to slowing economic growth.

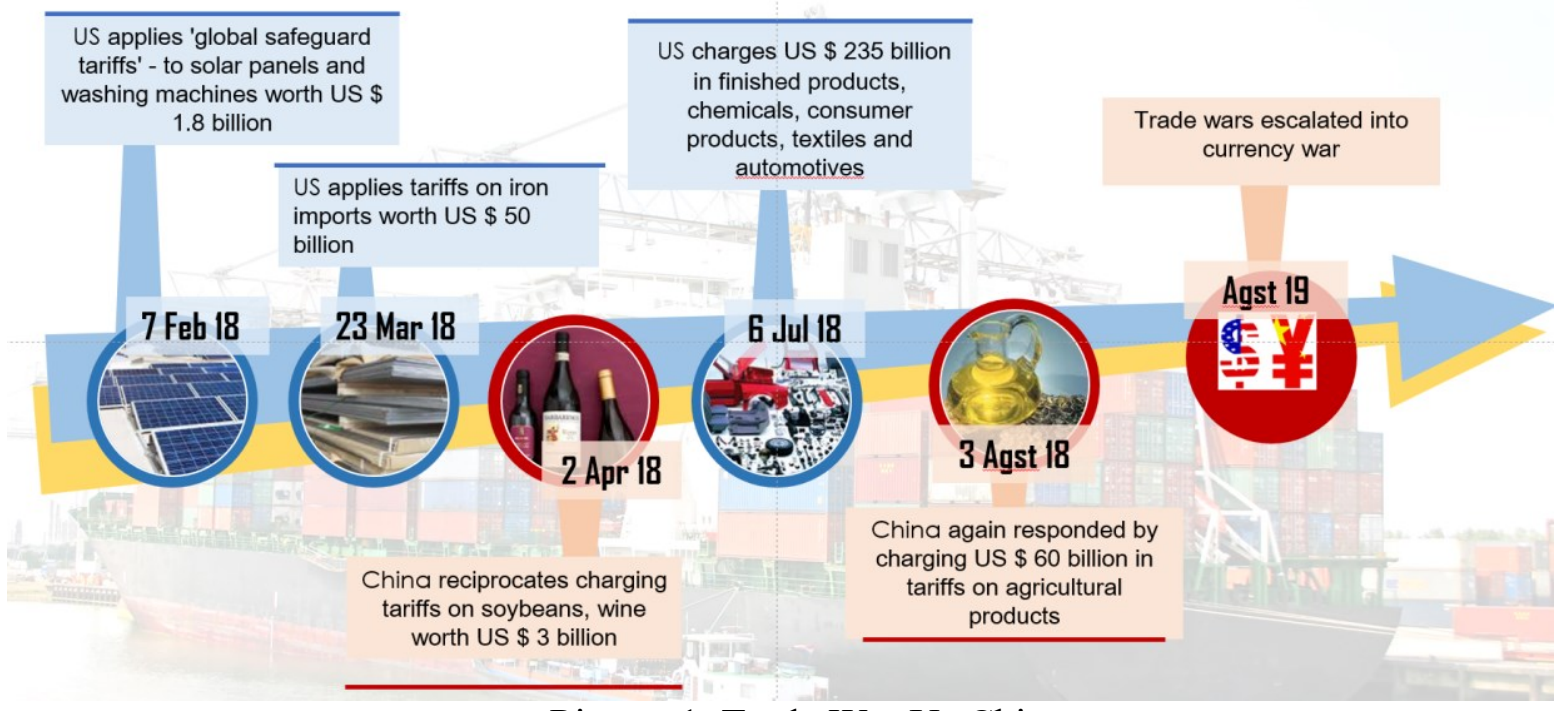

Picture 1. Trade War Us China

Source: Summary of various electronic media

The World Bank suggests that to resolve the above problems, not by limiting imports but by increasing investment. Because reducing the volume of trade will also result in a decline in economic growth (World Bank, September 2019).

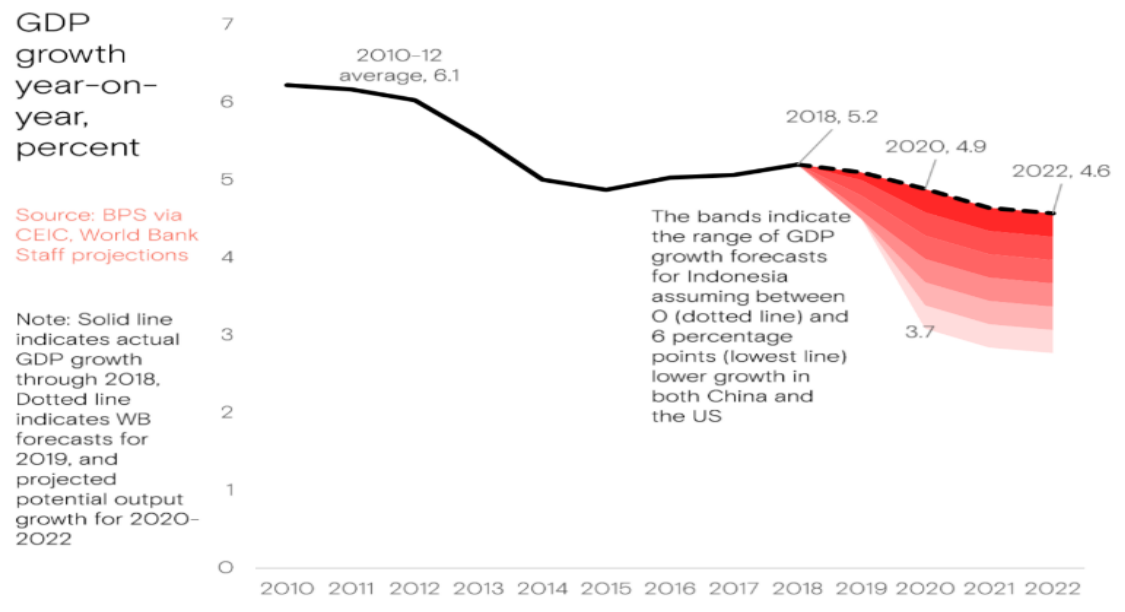

Picture 2. Indonesia Economic Growth Prediction

Source: Global economic risk and implications for Indonesia (World Bank 2019) 
One source of investment is foreign investment, one of them is through the establishment of multinational companies (MNC). It can increase economic growth, absorb labor forces, and increase exports. Zee, Stotsky, \& Ley, (2002) said that several mechanisms to attract MNCs were to provide tax incentives, one of the incentives that could be provided was export-oriented incentives. One of the export-oriented incentive schemes given by the Indonesian government to attract MNCs is the Bonded Zone. According to Minister of Finance Regulation (PMK) number 131 /PMK.04/2018 concerning the fourth amendment to PMK number 147/PMK.04/2011 concerning Bonded Zone. In Bonded Zones, companies obtain tax exemptions on imported raw materials and imported capital goods, but their products must be exported. Indonesia has experienced a significant increase in investment over the past 15 years with the Bonded Zone scheme, from 148 companies in 2002 to 1575 companies in 2017 (Indonesian Customs, January 2019). The last study of the impact of Foreign Direct Investment (FDI) on the Indonesian economy was conducted by Sjöholm, (1999) who showed that FDI was important for the economic growth of countries in east and southeast Asia, especially Indonesia. The calculation of the direct impact of companies operating on Bonded Zone has been carried out by the Indonesian Customs with the result that companies in Bonded Zone contribute 61 trillion rupiahs to the GRDP or around $16 \%$ of the total GRDP and absorb 400,000 workers.

Blomstrom \& Kokko, (1997), B. J. Aitken \& Harrison, (1999) said that MNCs in their activities also carry an indirect impact. One of them is when transferring technology to local companies. The technology transfer can occur directly, that is when the MNC opens cooperation with local companies, the MNC will teach the technology it carries or occurs indirectly when local companies copy products and technologies brought by MNC. Caves, (1974) said that technological progress will have a positive impact on a company's productivity. It is expected that the productivity of local companies can increase, with the transfer of technology from MNC. Based on this, MNC can bring positive externalities to the productivity of local companies. On the other hand, B. Aitken, Hanson, \& Harrison, (1997) also said that the presence of MNC also brings increased competition for local companies, both competition for resources, raw materials, human capital, and market competition. If the competition is too strong, local companies will experience an increase in production costs, making it difficult for local companies to develop and will instead 
exit the market or negative externalities. The results of empirical research on the presence of MNCs on the productivity of local companies in various countries show different effects, several studies found positive externalities on the presence of MNCs such as Liu, (2008) in China, while Waldkirch \& Ofosu, (2010) found MNCs had no effect what is the productivity of local companies in Ghana.

Empirical research on the impact of the presence of MNCs on the productivity of local companies in Indonesia still shows different results, Matthias Arnold \& Javorcik, (2009) found that most MNCs entering Indonesia had a Total Factor Productivity (TFP) lower by $6 \%$ from the average TFP local companies in Indonesia that are bigger and more mature in age. Suyanto et al., (2009) found that MNC productivity was higher than local companies but the study was only in the drug and chemical sector, they also found that MNC brought positive externalities to the productivity of local companies. Aitken, Hanson, \& Harrison, (1997) say the difference is due to the mutual attraction between the positive impact caused by transfer technology and the negative impact caused by the competition effect. Depending on which is stronger the impact will give different results. Differences in the impact of externalities according to Crespo and Fontoura (2007) can be influenced by various factors such as absorptive capacity, technological gap, and regional effect.

Next is the impact of Bonded Zone, MNCs operating in it obtain tax exemptions on raw materials and capital goods used, provided that their production proceeds for export, while MNCs that operate outside the Bonded Zone do not get tax exemptions and are not required to export their products. Companies operating in the export market are more productive than companies that only operate in the local market (Sharma \& Mishra, 2012). The difference is thought to affect the productivity and the impact of externalities between MNCs operating in Bonded Zone compared to those operating outside the Bonded Zone. The impact due to export obligations and the competition effect of MNCs operating in the Bonded Zone will be different from MNCs outside the Bonded Zone. To prove this opinion, Abraham, Konings, \& Slootmaekers, (2010) compared the impact of FDI externalities operating within the SEZ (Special Economic Zone) with FDI outside the SEZ in China. They found the externality of FDI on the SEZ to be almost the same as the FDI operating outside the SEZ, so it recommended for the Chinese government to reconsider the existence of the SEZ. 
Bonded Zone in Indonesia is spread in various cities in 8 provinces, unlike the SEZ in China which only exists in 6 cities in 3 provinces. Similarly, the technological conditions of manufacturing companies in China, which have advanced, the technology of the manufacturing industry in Indonesia is still developing. Because of these two different things, there is a suspicion that the externalities of MNC on Bonded Zone in Indonesia will be different from FDI externalities on SEZ in China. Based on this description, this research will recalculate the impact of MNC externalities in Indonesia. This study also distinguishes externalities between MNCs operating on Bonded Zone and those operating outside Bonded Zone by using a microdata analysis unit in the form of a 2011-2015 corporate annual tax report.

\section{LITERATURE REVIEW AND HYPOTHESIS DEVELOPMENT}

MNC is a company that works in at least 2 countries intending to increase profits. According to John H. Dunning, (1988), there are several reasons companies invest in other countries. Among others are:
a. Market Seeker
b. Efficiency seeker
c. Ownership and location advantages seeker
d. Resource seeker

Furthermore, as a guarantee of profitability, Görg et al., (2010) said that MNC requires more advanced technology compared to local companies in the investment destination country. By bringing more advanced technology, MNCs can be more productive than the destination country's local companies to ensure the goal of increasing profits can be achieved. With this assumption, local companies will obtain technology transfer both directly and indirectly in the presence of MNC.

Blomstrom \& Kokko, (1998) share how MNC transfers technology (Technology Transfer Channel) to local companies as follows:

\section{a. Direct technology transfer}

MNC directly influences technology through subsidiaries and subcontracts with local companies. By getting local companies to participate in the production chain, MNC will directly transfer technology. 
b. Indirect technology transfer

As stated by Blomstrom \& Kokko, (1998), Horizontal Spillover occurs when MNC activities influence local companies through the Demonstration Effect, Human Capital Effect, and Competition Effect.

The presence of MNC not only gives positive externalities but also brings negative externalities. That is due to several things as follows:

a. An example of a positive externality can be likened to a cotton company. Before the arrival of MNC, the company needed production costs at $\mathrm{P} 0$, so that it was only able to produce as much as Q1. This is depicted on the AC0 curve. But after the arrival of MNC engaged in the cotton sector by bringing new higher technology, local cotton companies were able to absorb the technology and operate more efficiently. Production costs decrease from $\mathrm{P} 0$ to $\mathrm{P} 1$ so the amount produced increases from Q0 to Q1. Technological advances brought by $\mathrm{MNC}$ can be replicated by local companies so that they can reduce average costs and become more productive (picture 3).

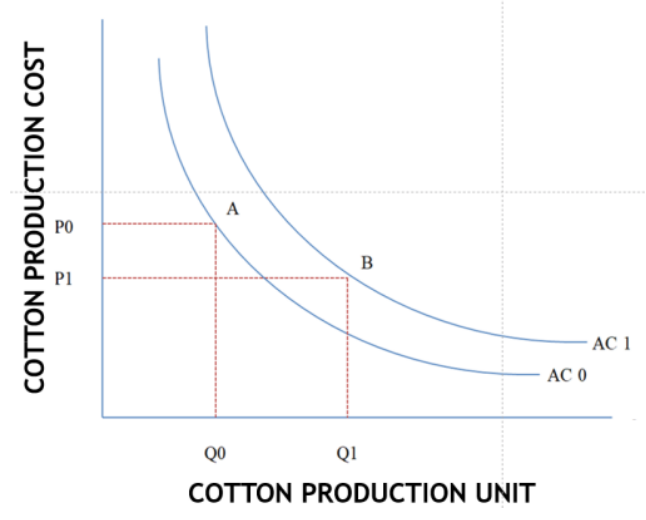

Picture 3. Positif Spillover

Source: interpreted from Aitken, Hanson, \& Harrison, (1997)

b. While examples of negative externalities are shown in picture 4, can be likened to an iron company. Before the arrival of $\mathrm{MNC}$, the company needed production costs at $\mathrm{P} 1$ so that it was able to produce as much as Q1, this is depicted on the $\mathrm{AC} 1$ curve. The arrival of MNCs in the iron sector increases competition for professional labor in the iron sector, local companies must pay higher salary burdens so that more efficient labor does not move to MNCs. This increases the production costs of local 
companies from $\mathrm{P} 1$ to $\mathrm{P} 2$ and decreases the productivity of local companies from $\mathrm{Q} 1$ to Q2.

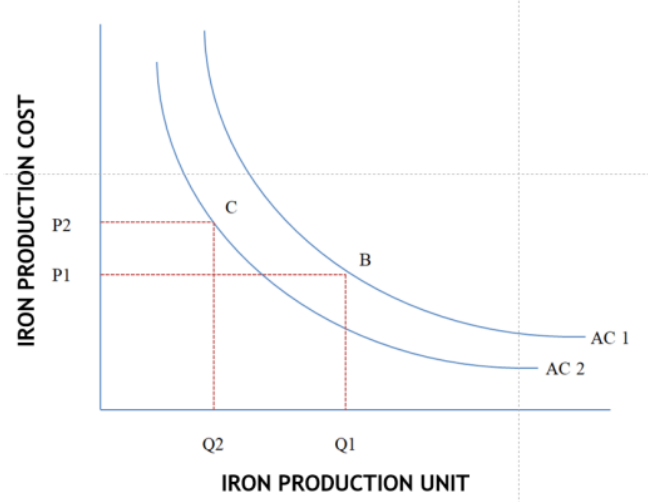

Picture 4. Negatif Spillover

Source: interpreted from Aitken, Hanson, \& Harrison, (1997)

c. The arrival of MNC in the cotton sector has a positive impact because it increases the productivity of local cotton producers, while the presence of $\mathrm{MNC}$ in the iron sector has a negative impact because it increases the costs of raw materials and labor, thereby reducing the productivity of local iron producers. With this illustration, Total Factor Productivity on cotton production and iron production is the most appropriate instrument used to measure the presence of MNC externalities or not and which is more dominant, whether the positive effects of technological learning or the negative effects of competition are more dominating (picture 5).

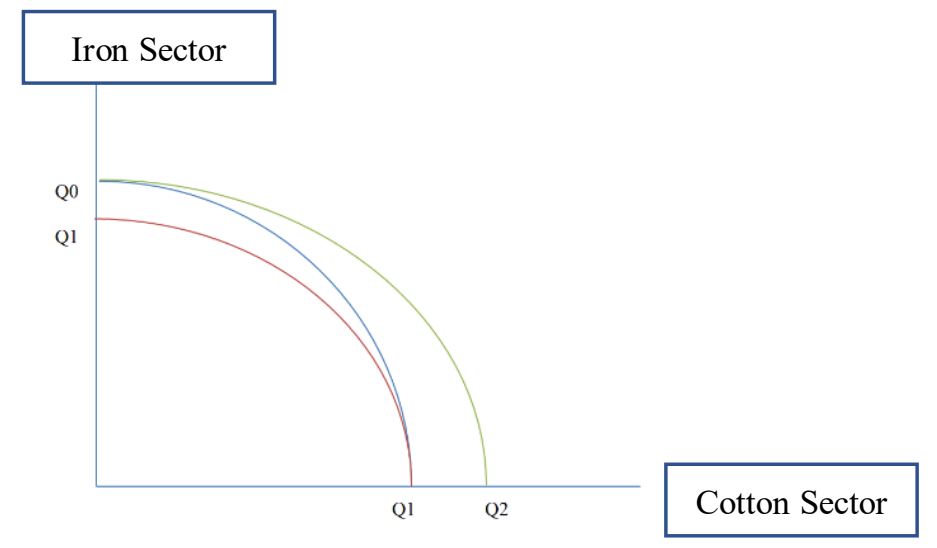

Picture 5. Production Possibility Frontier Source: interpreted from Aitken, Hanson, \& Harrison, (1997)

Crespo \& Fontoura, (2007) said that externalities are influenced by various factors such as absorptive capacity, technological gap, and regional effect. Technology differences that are too small make local companies not get new technology, while 
differences that are too large make it difficult for local companies to emulate. Based on regional boundaries, the farther away from local companies and MNCs are, the smaller the impact of externalities. This is due to the higher transportation costs (Girma 2003). So that in general the biggest MNC impact only occurs to local companies that are in the same region with the MNC.

MNCs on Bonded Zone are permitted to work with local companies through subcontracting schemes, as well as there are no restrictions on employee recruitment to Bonded Zone, so MNCs on Bonded Zone can provide positive spillovers to companies in the same sector or horizontal spillover. Because MNCs operating in Bonded Zone obtain import tax exemptions on raw materials and capital goods used, they work more efficiently and productively. Amiti \& Konings, (2016), Mayende, (2013) and Halpern, Koren, \& Szeidl, (2015) have proven that companies that obtain tariff reductions taxes on the purchase of intermediate goods and capital goods, work becomes more efficient and more productive.

Lu, (2010) and Sharma, (2017) say that companies operating in the export market are also more productive than companies that only operate in the local market. MNCs in Bonden Zone can allocate funds to adopt better new technologies with tax incentives, for example investing in more sophisticated machines and more productive human resources. MNCs that are in Bonden Zone are more productive, have higher technology, and have better export market access compared to MNCs that are outside of Bonden Zone, indirectly will create higher positive externalities. The MNC competition effect in the Bonden Zone will be lower than the MNC in the Bonden Zone and make negative externalities lower with export obligations and local sales limits.

Research conducted by Abraham et al., (2010) in China measures the externality impact of the presence of MNCs in the Special Economic Zone (SEZ), they found that MNCs on SEZ in China carry almost the same externalities as MNCs outside of SEZ. So with these results, Abraham, Konings, \& Slootmaekers, (2010) suggested that the Chinese government consider the tax incentives provided through the Special Economic Zone (SEZ) scheme. In Indonesia, it is suspected that there is a difference in technology difference between MNCs in China and local companies in China compared to MNCs in Indonesia with local companies in Indonesia, as well as the location and distribution of 
Chinese SEZs and Bonded Zone in Indonesia, so it is necessary to calculate the impact of MNC externalities on Bonded Zone in Indonesia.

So, the hypotheses to be tested in this study are as follows :

a. That $\mathrm{MNC}$ is more productive than local companies and has positive externalities:

i. $\mathrm{H}_{0}$ : MNC has the same TFP from a local company, $\gamma_{1}=0 . \mathrm{H}_{1}$ : MNC has a TFP greater than a local company, $\gamma_{1}>0$.

ii. $\mathrm{H}_{0}$ : MNC does not have an externality to the local company's TFP, $\delta_{1}=0$. H 1 : MNC has a positive externality towards the local company's TFP, $\delta_{1}>0$

b. That MNCs that carry out export activities are more productive than MNCs that do not export and have greater externalities:

i. $\mathrm{H}_{0}:$ MNC which conducts export and import activities has the same TFP from MNC which only operates in the local market, $\gamma_{2}=0 . \mathrm{H}_{1}$ : MNC which conducts export and import activities has a TFP greater than MNC which only operates in the local market, $\gamma_{2}>0$.

ii. $\mathrm{H}_{0}$ : MNC which does export activities has the same externality as MNC which does not export, $\delta_{2}=0 . \mathrm{H}_{1}$ : MNC that does export activities has a greater externality than MNC that does not export, $\delta_{2}>0$.

c. That MNCs carrying out export activities at Bonded Zone is more productive than MNCs outside Bonded Zone and have greater externalities:

i. $\mathrm{H}_{0}$ : MNC which is in Bonded Zone has a TFP the same from MNC which carries out export activities, $\gamma_{3}=0 . \mathrm{H}_{1}:$ MNC which is in Bonded Zone has a TFP greater than MNC which carries out export activities, $\gamma_{3}>0$.

ii. $\mathrm{H}_{0}$ : MNCs in the Bonded Zone has the same TFP from MNCs that carry out export activities, $\delta_{3}=0 . \mathrm{H}_{1}$ : MNCs in Bonded Zone have greater externalities than MNCs outside the bonded zone, $\delta_{3}>0$.

\section{RESEARCH METHODS}

To find out the impact of MNC on local companies, Abraham et al., (2010) measured the productivity growth of local companies at the location of the MNC. The variable used to measure productivity is Total Factor Productivity (TFP). The dependent 
variable in this study is Total Factor Productivity (TFP) or company productivity. The approach commonly used to estimate productivity is through the company's production function as follows:

$Y_{i t}=\mathrm{A}_{i t}\left(L_{i t}^{\beta l} K_{i t}^{\beta k}\right)$

where $\mathrm{Y}$ is output, $\mathrm{L}$ is labor, and $\mathrm{K}$ is Capital, while $\mathrm{A}$ is the measure of a company's technical progress (i) in period ( $\mathrm{t}$ ). By taking the natural logarithm of the above equation, we find:

$\ln \left(Y_{i t}\right)=\beta_{0}+\alpha \ln L_{i t}+\beta \ln K_{i t}+$

Or

$\ln \left(Y_{i t}\right)=\ln (A)_{i t}+\alpha \ln L_{i t}+$ $\beta \ln K_{i t}$

So

$\ln (A)_{i t}=\beta_{0}+$

$\vartheta_{i t}$

The estimation method above is considered vulnerable to bias, the production input of a company is influenced by company characteristics, and the company's reaction in the face of external shock. De Loecker, (2007) said when positive shock production occurs, for example when holding overtime. will cause upward bias in $\mathrm{K}$, then when there is a negative shock to production, for example, workers on strike will make the capital coefficient downward biased. So the calculation of TFP using ordinary OLS will be biased and inconsistent. To overcome this problem, it is recommended for simultaneous models with instrument variables that are not affected by shock, in this case, what is suggested by is an investment in the previous year, because an investment is determined one period earlier so that it is not affected by simultaneous bias.

$\operatorname{Inv} v_{i t}=$

$f_{t}\left(\omega_{i t}, K_{i t}\right)$

In the use of investment variables, the problem is that there is often no investment growth between years so Levinsohn \& Petrin (2003) cannot be calculated. Another variable that is suggested is to use Intermediate Input where the input demand of a company is a function of the capital owned by the company and its progress technology. The first is to add raw materials to the production function so that they become: 
$Y_{i t}=\mathrm{A}_{i t}\left(L_{i t}^{\beta l} K_{i t}^{\beta k} M_{i t}^{\beta m}\right)$

then by taking the natural logarithm so it becomes:

$\ln \left(Y_{i t}\right)=\beta_{0}+\beta_{l} \ln L_{i t}+\beta_{k} \ln K_{i t}+\beta_{m} \ln m_{i t}+$

$\vartheta_{i t}$

where $\beta_{0}$ is productivity differences between companies and $\vartheta_{i t}$ is the total of unobservable technological progress, management progress, and error. So that it can be broken down again into:

$\ln \left(Y_{i t}\right)=\beta_{0}+\beta_{l} \ln L_{i t}+\beta_{k} \ln K_{i t}+\beta_{m} \ln m_{i t}+\omega_{i t}+$

$\varepsilon_{i t}$

because the input is influenced by the capital owned by the company and its technological progress, then

$m_{i t}=$

$g_{t}\left(\omega_{i t}, K_{i t}\right)$

......(9)

because strictly monotonicity, then

$\omega_{i t}=$ $g_{t}^{-1}\left(m_{i t}, K_{i t}\right)$

$\omega_{i t}=$

$s_{t}\left(m_{i t}, K_{i t}\right)$

then to overcome the simultaneous bias problem, add (9) to (8) so that it becomes

$y_{i t}=\beta_{l} l_{i t}+s_{t}\left(m_{i t}, k_{i t}\right)+$

$\varepsilon_{i t}$

where

$s_{t}\left(m_{i t}, k_{i t}\right)=\beta_{0}+\beta_{k} \ln K_{i t}+\beta_{m} m_{i t}+$

$\omega_{i t}\left(m_{i t}, K_{i t}\right)$.

by using the Generalized Method of Moment (GMM, Levinsohn \& Petrin, (2003) we can obtain $\beta_{l}$ on the first estimate and coefficients $\beta_{k}$ and $\beta_{m}$ the second stage estimation.

After measuring productivity, then we measure the presence of $\mathrm{MNC}$ in an area where local companies are located. To measure the presence of MNC in an area, this study uses the marketshare model proposed by B. Aitken et al., (1997). Marketsharemnc as an illustration of the presence of MNC in each province of each sector is all MNC company output divided by total company output. 
Marketsharemnc ${ }_{j}=$

$\frac{\sum_{i} \text { dummymnc }_{i j t} . \text { output }_{i j t}}{\Sigma_{1} \text { output }}$

To prove the existence of MNC to bring externalities to local company productivity, a model that is adapted from the research conducted is used by Abraham et al., (2010). Abraham et al., (2010) included the MNC presence variable in the form of Marketsharemnc for work productivity growth as illustrated by $\ln$ (TFP). The first is to make the local company TFP as the main variable and use the market sharemnc as the control variable.

$\ln (\text { TFP })_{i t}=\delta_{0}+\delta_{1}$ Marketsharemnc $_{j t}+\gamma_{1}$ dummymnc $_{i}+d_{p}+d_{j}+d_{t}+$ $\varepsilon_{i t}$

Next is the existence of proving the suspicion that MNCs which do export are more productive so that they provide greater positive externalities than MNCs that do not export. By separating MNCs from exporting and those not using dummyexporters and interacting with marketshare.

$\ln (\text { TFP })_{i t}=\delta_{0}+\delta_{1}$ Marketsharemnc $_{j t}+\delta_{2}$ Marketsharemnc $_{j t} x$ dummyeksportir $_{i t}+$

$\gamma_{1}$ dummymnc $_{i}+\gamma_{2}$ dummyeksportir $_{i}+d_{p}+d_{j}+d_{t}+$

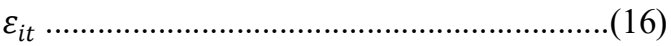

Last is to prove the suspicion that MNCs operating on Bonded Zone are more productive so that they provide greater positive externalities than MNCs outside of Bonded Zone. By separating MNCs using dummykb and interacting with marketshare.

$\ln (\text { TFP })_{i j}=\delta_{0}+\delta_{1}$ Marketsharemnc $_{j t}+\delta_{2}$ Marketsharemnc $_{j t} x$ dummyeksportir $_{i t}+$ $\delta_{3}$ Marketsharemnc $_{j t} x$ dummyKB $_{i t}+\gamma_{1}$ dummymnc $_{i}+\gamma_{2}$ dummyeksportir $_{i}+\gamma_{3}$ dummykb $_{i}+$ $\delta_{4}$ lndipa $+\delta_{5} \operatorname{lnj} \ln +d_{p}+d_{j}+d_{t}+$ $\varepsilon_{i t}$

while the control used in this measurement is the role of government in increasing public goods which is described by the amount of government expenditure and road conditions as a control (Girma 2003), the next control is the technological similarity and regional effects of Crespo \& Fontoura, (2007). By using provincial dummy to distinguish regional effects and business sector dummy to distinguish technological similarities.

The data used are company data reported to the Directorate General of Taxes on the Special Reports Tax Form 8A-I. In the Y variable which is the company's output the total net sales data is used, the $\mathrm{K}$ variable uses the value of land and buildings, the $\mathrm{L}$ variable 
uses direct labor costs and for the variable $\mathrm{M}$ uses the value of raw materials used. Wheres the dipa variable which is the role of the government in increasing the number of public goods in one region is used by the provincial government budget data at the Central Statistics Agency (BPS). The length of roads per provincial area is also obtained from the Land Transportation Statistics report issued annually by BPS. To measure TFP, production variables such as $\mathrm{Y}, \mathrm{K}, \mathrm{L}$, and $\mathrm{M}$. are required.

Tabel 1

Explanation Of Variables

\begin{tabular}{|c|c|c|}
\hline Var & Definition & Source \\
\hline dummyMNC & is the separation of whether the company is an $\mathrm{MNC}$ or not & INA Customs \\
\hline dummyexporters & $\begin{array}{l}\text { is the separation of whether the company is an exporter or } \\
\text { not }\end{array}$ & INA Customs \\
\hline dummykb & $\begin{array}{l}\text { is the separation of whether the company is located in the } \\
\text { bonded zone or not }\end{array}$ & INA Customs \\
\hline$Y$ & $\begin{array}{l}\text { The output value of each business of the company in units } \\
\text { of rupiah }\end{array}$ & Tax Report \\
\hline $\mathrm{K}$ & $\begin{array}{l}\text { The value of capital in the form of land and buildings of } \\
\text { each company in units of rupiah }\end{array}$ & Tax Report \\
\hline $\mathrm{L}$ & $\begin{array}{l}\text { The value of the company's workforce both permanent and } \\
\text { non-permanent employees of each company in units of } \\
\text { rupiah }\end{array}$ & Tax Report \\
\hline $\mathrm{M}$ & $\begin{array}{l}\text { The value of raw materials used in each company in units } \\
\text { of rupiah }\end{array}$ & Tax Report \\
\hline export & $\begin{array}{l}\text { The output value of a company that is sold on foreign } \\
\text { markets (export) in units of rupiah }\end{array}$ & Tax Report \\
\hline dipa & Government budget of each province in the unit of rupiah & $\begin{array}{l}\text { Central } \\
\text { Bureau of } \\
\text { Statistics }\end{array}$ \\
\hline jlnperluas & $\begin{array}{l}\text { The total length of the road is divided by the area of each } \\
\text { province in percentage }\end{array}$ & $\begin{array}{l}\text { Central } \\
\text { Bureau of } \\
\text { Statistics }\end{array}$ \\
\hline deflator & $\begin{array}{l}\text { Deflator uses a price index based on } 2010 \text { which is then } \\
\text { propagated }\end{array}$ & $\begin{array}{c}\text { Central } \\
\text { Bureau of } \\
\text { Statistics }\end{array}$ \\
\hline Kode_pro & Is the province code with a total of 34 provinces & - \\
\hline Kode_klu & Is the business field code with a total of 23 code & Tax Report \\
\hline Year & Is tax year & Tax Report \\
\hline
\end{tabular}




\section{ANALYSIS AND DISCUSSION}

The data we have consisted of 6,079 companies with 30,395 observations. Our panel data is included in the balanced panel. The problem is that there is an inequality that is too high on the road variable because there are values below $1 \%$ and above $99 \%$ where the smallest value is in the provinces of Papua and North Kalimantan compared with the largest value in the province of DKI Jakarta. But given that there are MNCs in the province which were the main objective of the study, the data was not deleted. While the division according to the business category of the company is divided into 34 (thirtyfour) business field.

Tabel 2

Statistic Descriptif

\begin{tabular}{ccccccc}
\hline Var & Obs & Unit & Mean & Std.Dev & Min & Max \\
\hline Y & 12002 & M Rp & 217,0 & 1,270 & 0 & 51,000 \\
K & 17695 & M Rp & 63,3 & 364 & 0 & 16,000 \\
L & 12002 & M Rp & 9,3 & 30 & 0 & 830 \\
M & 12002 & M Rp & 140,0 & 923 & 0 & 39,000 \\
Exp & 15705 & M Rp & 24,4 & 333 & 0 & 16,000 \\
dipa & 17695 & M Rp & 19,8 & 14 & 0 & 53 \\
jln & 17695 & $\%$ & $158 \%$ & $234 \%$ & $0 \%$ & $686 \%$ \\
& Source: processed form the Directorate General of Taxes, 2011-2015.
\end{tabular}

As a basis for research, first calculate TFP according to the method used by (Levinsohn \& Petrin, 2003).

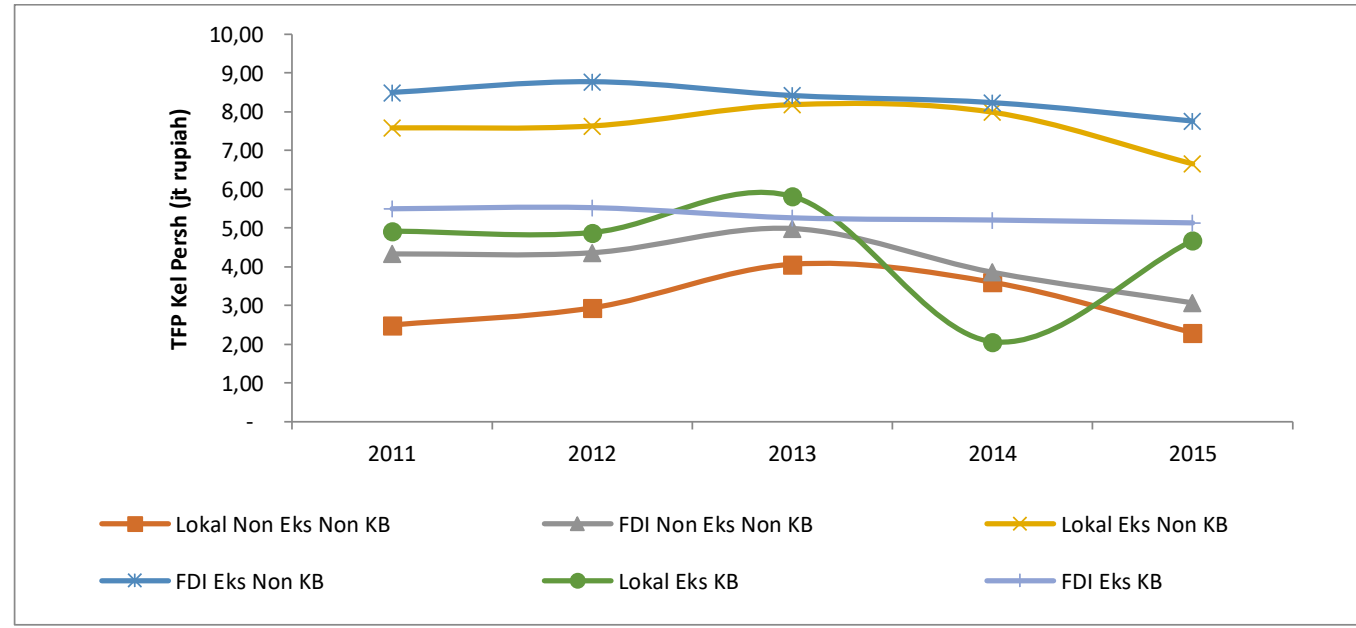

Picture 6. TFP_LP

Source: Stata Output

As per picture 6, it is found that MNCs are more productive than local companies and MNC exporters are far more productive than MNCs in general while MNCs that 
operate on Bonded Zone is more productive than MNCs that only operate on local markets but are less productive than MNCs outside of Bonded Zone that export.

Next, we look at the relationship between Marketsharemnc and lnTFP of local companies.

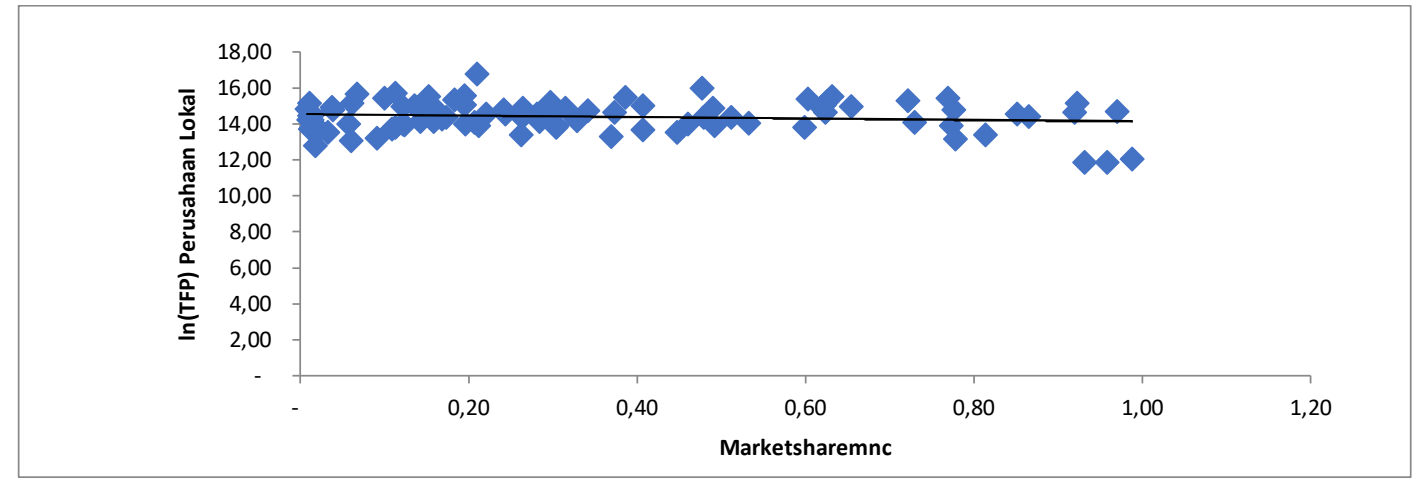

Picture 7. Growth In Ln(TFP) Compared To Marketsharemnc Source: Stata Output.

From picture 7, it was found that the marketshare of the CNC company had a positive impact on the LN (TFP) of local companies when it was below 0.5 but after the above 0.5 market markets had a negative effect.

Tabel 3

Estimation Result

\begin{tabular}{|c|c|c|c|c|c|}
\hline VARIABLES & $\begin{array}{l}(1) \\
\operatorname{lnTFP}\end{array}$ & $\begin{array}{l}(2) \\
\operatorname{lnTFP}\end{array}$ & $\begin{array}{l}(3) \\
\operatorname{lnTFP}\end{array}$ & $\begin{array}{l}(4) \\
\operatorname{lnTFP}\end{array}$ & $\begin{array}{l}(5) \\
\operatorname{lnTFP}\end{array}$ \\
\hline Marketsharemnc & $\begin{array}{l}0.85^{* * * *} \\
(0.10)\end{array}$ & $\begin{array}{l}1.06^{* * *} \\
(0.13)\end{array}$ & $\begin{array}{l}1.04 * * * \\
(0.13)\end{array}$ & $\begin{array}{l}1.03 * * * \\
(0.13)\end{array}$ & $\begin{array}{l}1.03 * * * \\
(0.13)\end{array}$ \\
\hline $\begin{array}{l}\text { Marketsharemnc* } \\
\text { dummyeksp }\end{array}$ & & $\begin{array}{l}-0.40 * * * \\
(0.12)\end{array}$ & $\begin{array}{l}-0.44 * * * \\
(0.12)\end{array}$ & $\begin{array}{l}-0.44 * * * \\
(0.12)\end{array}$ & $\begin{array}{l}-0.44 * * * \\
(0.12)\end{array}$ \\
\hline Marketsharemnc*dumykb & & & $\begin{array}{l}0.62 * * \\
(0.31)\end{array}$ & $\begin{array}{l}0.61 * * \\
(0.31)\end{array}$ & $\begin{array}{l}0.61 * * \\
(0.31)\end{array}$ \\
\hline dummymnc & $\begin{array}{l}0.086^{*} \\
(0.04)\end{array}$ & $\begin{array}{l}-0.26^{* * *} \\
(0.04)\end{array}$ & $\begin{array}{l}-0.25 * * * \\
(0.04)\end{array}$ & $\begin{array}{l}-0.25 * * * \\
(0.04)\end{array}$ & $\begin{array}{l}-0.25^{* * *} \\
(0.04)\end{array}$ \\
\hline dummyeksp & & $\begin{array}{l}1.03 * * * \\
(0.03)\end{array}$ & $\begin{array}{l}1.03 * * * \\
(0.03)\end{array}$ & $\begin{array}{l}1.03 * * * \\
(0.03)\end{array}$ & $\begin{array}{l}1.03 * * * \\
(0.03)\end{array}$ \\
\hline dummykb & & & $\begin{array}{l}-0.12 \\
(0.11)\end{array}$ & $\begin{array}{l}-0.12 \\
(0.11)\end{array}$ & $\begin{array}{l}-0.12 \\
(0.11)\end{array}$ \\
\hline lndipa & & & & $\begin{array}{l}0.36 \\
(0.22)\end{array}$ & $\begin{array}{l}0.39^{*} \\
(0.23)\end{array}$ \\
\hline jlnperluas & & & & & $\begin{array}{l}-0.13 \\
(0.35)\end{array}$ \\
\hline Constant & $\begin{array}{l}13.60 * * * \\
(0.1)\end{array}$ & $\begin{array}{l}13.38 * * * \\
(0.1)\end{array}$ & $\begin{array}{l}13.39^{* * * *} \\
(0.1)\end{array}$ & $\begin{array}{l}7.95 * * \\
(3.32) \\
\end{array}$ & $\begin{array}{l}7.63 * * \\
(3.42) \\
\end{array}$ \\
\hline Observations & 11,53 & 11,53 & 11,53 & 11,53 & 11,53 \\
\hline R-squared & 0.18 & 0.28 & 0.28 & 0.28 & 0.28 \\
\hline
\end{tabular}


The estimation results in table 3 show that MNCs are more productive by $0.0868 \%$ than local companies. Then after separating between MNCs that export and those that do not export, it is found that MNCs that export is more productive. The last is to separate MNCs in Bonded Zone with MNCs outside Bonded Zone, the results show that MNCs operating in Bonded Zone are more productive than MNCs that only operate in the local market, but not more productive than MNCs that export outside Bonded Zone. In estimating the impact of Marketsharemnc on the productivity of local companies, it was found that the presence of MNCs on the domestic market had a positive impact on the productivity of local companies. Where every $1 \%$ increase in Marketharemnc impacts $0.85 \%$ increase in productivity of local companies. But even though it is more productive, the externalities between MNCs that do export activities are even lower than MNCs that do not export. Every 1\% increase in Marketshare MNC which exports has a $0.62 \%$ increase in productivity of local companies. This is allegedly due to the technology gap that is too high so that local companies do not have a positive impact on technology transfer. (Image 1). While the MNC externalities in the Bonded Zone showed the highest results, where every $1 \%$ increase in Marketshare MNC in the Bonded Zone had a $1.20 \%$ impact.

These findings are following the hypothesis proposed as follows:

a. That MNC in Indonesia is more productive than local companies and has positive externalities. This is different from the findings of Matthias Arnold \& Javorcik (2009) and completes the research by Suyanto et al., (2009).

b. That MNCs that carry out export activities are more productive than MNCs that do not export and have greater externalities. These findings are consistent with the findings of Lu, (2010) and Sharma, (2017).

c. That MNCs carrying out export activities at Bonded Zone is more productive than MNCs outside Bonded Zone and have greater externalities. This is different from research conducted by Abraham et al., (2010) in China.

d. The role of the government in providing public goods has a positive impact on company productivity. Every $1 \%$ increase in dipa will increase company productivity by $0.39 \%$. The addition of roads did not have a significant impact on the company's 
productivity growth. This occurs due to data with values below $1 \%$ and above $99 \%$ in the provinces of Papua and North Kalimantan and DKI Jakarta.

All industrial sectors received positive externalities, it was found that the highest positive externalities were found in the cigarette industry while the lowest external impacts were on the handicraft industry which could not be classified (Table 3).

Tabel 4

Externalities By Business Field Group

\begin{tabular}{cc}
\hline Business Field Group & Externalities \\
\hline Industri rokok & $0.862^{* * *}$ \\
Industri pengolahaan minyak & $0.502^{* *}$ \\
Industri Besi Baja & $0.243^{* * *}$ \\
& \\
& $-0.942^{* * *}$ \\
Industri pengolahan kayu & $-0.815^{* * *}$ \\
Industri percetakan & $-0.954^{* * *}$ \\
Kerajinan YTDL
\end{tabular}

Furthermore, on the impact by province (Table 4), it was found that the province that received the most positive externalities was Bengkulu province, while the province with the lowest externality was Papua.

Tabel 5

Externalities By Province

\begin{tabular}{cc}
\hline Province & Externalities \\
\hline Bengkulu & $1.849^{* * *}$ \\
Jambi & $1.584^{* * *}$ \\
Kalimantan Selatan & $1.514^{* * *}$ \\
& \\
Maluku & -0.0110 \\
Nusa Tenggara & $-1.445^{* *}$ \\
Papua & $-1.559^{*}$ \\
\hline & Source: Stata Output
\end{tabular}

As for Bonded Zone, the data held only includes data on bonded zones in 8 provinces and $14 \mathrm{KLU}$. Bonded Zone that has the highest positive externality is in the province of Jakarta, then the one that gives the lowest externality is in the province of Bali (Table 6). This is alleged because local companies in Jakarta have the lowest technology gap, so they can easily imitate the technology brought by MNC. While for Bali is suspected because many MNC's in Bali give stronger competitive impact on local companies than technology transfer. 
Tabel 6

Externalities MNC In Bonded Zone By Province

\begin{tabular}{cc}
\hline Province Name & Eksternalitas \\
\hline DKI Jakarta & $1.311^{* * *}$ \\
Sumatera Selatan & $1.101^{* * *}$ \\
Jawa Timur & 0.225 \\
Bali & 0 \\
\hline \multicolumn{2}{c}{ Source: Stata Output }
\end{tabular}

The impact of externalities by business field group (Table 7), it was found that MNC gave the highest externality to Bonded Zone MNCs operating in the food processing sector. This is thought to be because the food market is large enough so that the impact of competition arising from food MNCs is very low. Then for the lowest externalities in the handicraft sector (manufacturing medical equipment, music equipment, etc.), this is alleged because the industry has a very specific technology so that local companies find it difficult to imitate the technology brought by the MNC.

Tabel 7

Externalities MNC By Business Field Group

\begin{tabular}{cc}
\hline Business Field Group & Externalities \\
\hline Industri pengolahan makanan & 0 \\
Industri pengolahan Kayu & $-0.942^{* * *}$ \\
Kerajinan YTDL & $-0.954 * *$ \\
\hline \multicolumn{2}{c}{ Source: Stata Output }
\end{tabular}

Finally, on annual growth, although it is found to be positive, the impact of MNC externalities always decreases every year (table 8). This shows that every year the MNC that brings high technology is decreasing while the MNC that brings competition is increasing.

Tabel 8

MNC Externalities By Year

\begin{tabular}{cc}
\hline Year & Externalities \\
\hline 2012.year & 0.0146 \\
2013.year & $0.217^{* *}$ \\
2014.year & 0.111 \\
2015.year & $-0.185^{*}$ \\
\hline \multicolumn{2}{c}{ Source: Stata Output }
\end{tabular}




\section{CONCLUSION AND POLICY RECOMMENDATIONS}

This study measures the impact of MNC externalities on the productivity of local companies. Furthermore, this study also measured the differences in externalities of MNCs operating in Bonded Zone and those operating outside of Bonded Zone. An externality is measured by the growth of local company TFP with the market share of MNC. Estimation results indicate a positive externality on the arrival of MNC on the local company TFP. But although overall MNCs bring positive externalities to the productivity of local companies, MNCs operating on Bonded Zone have a greater externality impact than MNCs that operate outside Bonded Zone.

The results of this study have implications for the determination of government program policies to attract foreign investment in the form of tax incentives in this case that Bonded Zone is following its original purpose. Some of the policies that can be taken from the above research are as follows

1. To ensure MNC continues to increase its productivity, the government can provide several incentives such as:

a. Tax ease of research and development.

b. Workforce training cooperation between the government and companies.

2. To ensure externalities occur to local companies, the government needs to ensure a positive relationship exists between MNCs and local companies such as :

a. The difference in tax incentives when an MNC engages in subcontracting with a local company

b. The difference in stimulus in the use of domestic raw materials is a certain percentage

Bonded zones are good instruments for governments to attract MNC. The most important thing is to continue to measure and maintain the intensity of MNC's spillover and competition effect on local companies. The government needs to map the location of provinces and industries that experience negative externalities and make appropriate policies to increase their positive externalities. 


\section{REFERENCES}

Abraham, F., Konings, J., \& Slootmaekers, V. (2010). FDI spillovers in the Chinese manufacturing sector. Economics of Transition, 18(1), 143-182. https://doi.org/10.1111/j.1468-0351.2009.00370.x

Aitken, B., Hanson, G., \& Harrison, A. (1997). Spillovers, foreign investment, and export behavior. Journal of International Economics, 43, 103-132. https://doi.org/10.1016/S0022-1996(96)01464-X

Aitken, B. J., \& Harrison, A. E. (1999). Do domestic firms benefit from a direct foreign investment? Evidence from Venezuela. American Economic Review, 89(3), 605618. https://doi.org/10.1257/aer.89.3.605

Amiti, B. M., \& Konings, J. (2016). American Economic Association Trade Liberalization, Intermediate Inputs, and Productivity: Evidence from Indonesia Author ( s ): Mary Amiti and Jozef Konings Source: The American Economic Review, Vol. 97, No . 5 ( Dec ., 2007 ), pp. 1611-1638 Publ, 97(5), 1611-1638.

Blomstrom, M., \& Kokko, A. (1998). Multinational Corporations and Spillovers. Journal of Economic Surveys, 12(3), 247-277. https://doi.org/10.1111/14676419.00056

Caves, R. E. (1974). Multinational Firms, Competition, and Productivity in Host-Country Markets. Economica Volume 41 Issue 162 1974, 41(162), 176-193. https://doi.org/10.2307/2553765

Crespo, N., \& Fontoura, M. P. (2007). Determinant Factors of FDI Spillovers - What Do We Know? World Development, 35(3), 410-425. https://oi.org/10.1016/j.worlddev.2006.04.001

Das, S. (1987). Externalities, and technology transfer through multinational corporations. Journal of International Economics, 22, 171-182.

De Loecker, J. (2007). Do exports generate higher productivity? Evidence from Slovenia. Journal of International Economics, 73(1), 69-98. https://doi.org/10.1016/j.jinteco.2007.03.003

Dunning, J. H. (1988). The theory of international production. The International Trade Journal, 3(1), 21-66. https://doi.org/10.1080/08853908808523656

Flôres, R. G., Fontoura, M. P., \& Santos, R. G. (2007). Foreign direct investment spillovers in Portugal: Additional lessons from a country study. European Journal of Development Research, 19(3), 372-390. https://doi.org/10.1080/09578810701507126

Girma, S., \& Gong, Y. (2008). FDI, linkages, and the efficiency of state-owned enterprises in China. Journal of Development Studies, 44(5), 728-749. https://doi.org/10.1080/00220380802009233

Girma, S., Kneller, R., \& Pisu, M. (2007). Do exporters have anything to learn from foreign multinationals? European Economic Review, 51(4), 993-1010. https://doi.org/10.1016/j.euroecorev.2006.07.003

Görg, H., \& Greenaway, D. (2004). Much ado about nothing? Do domestic firms benefit from the foreign direct investment? World Bank Research Observer, 19(2), 171- 
197. https://doi.org/10.1093/wbro/lkh019

Görg, H., Greenaway, D., Keller, W., Yeaple, S., Kim, S., Aitken, B., ... Kokko, A. (2010). FDI Spillovers and Time since Foreign Entry. World Development, 43(1), 62-74. https://doi.org/10.1016/0305-750X(83)90016-5

Halpern, L., Koren, M., \& Szeidl, A. (2015). Imported inputs and productivity. American Economic Review, 105(12), 3660-3703. https://doi.org/10.1257/aer.20150443

Levinsohn, J., \& Petrin, A. (2003). Estimating Production Functions Using Inputs to Control for Unobservables Estimating Production Functions Using Inputs to Control for Unobservables. Review of Economic Studies, 70(70), 317-341. https://doi.org/10.1111/1467-937X.00246

Liu, Z. (2008). Foreign direct investment and technology spillovers: Theory and evidence. Journal of Development Economics, 85(1-2), 176-193. https://doi.org/10.1016/j.jdeveco.2006.07.001

Lu, D. (2010). Exceptional Exporter Performance? Evidence from Chinese Manufacturing Firms. Working Papers. Retrieved from http://www.gsb.stanford.edu/FACSEMINARS/events/economics/documents/econ_ 01_11_Lu.pdf

Madani, D. (1999). A Review of the Role and Impact of Export Processing Zones, (August). https://doi.org/10.1596/1813-9450-2238

Markusen, J. R., \& Trofimenko, N. (2009). Teaching locals new tricks: Foreign experts as a channel of knowledge transfers. Journal of Development Economics, 88(1), 120-131. https://doi.org/10.1016/j.jdeveco.2008.02.002

Matthias Arnold, J., \& Javorcik, B. S. (2009). Gifted kids or pushy parents? Foreign direct investment and plant productivity in Indonesia. Journal of International Economics, 79(1), 42-53. https://doi.org/10.1016/j.jinteco.2009.05.004

Mayende, S. (2013). The Effects of Tax Incentives on Firm Performance: Evidence from Uganda. Journal of Politics and Law, 6(4), 95-107. https://doi.org/10.5539/jpl.v6n4p95

Sharma, C. (2017). Exporting, access to foreign technology, and firms' performance: Searching the link in Indian manufacturing. Quarterly Review of Economics and Finance. https://doi.org/10.1016/j.qref.2017.11.015

Sharma, C., \& Mishra, R. K. (2012). Export participation and productivity performance of firms in the Indian transport manufacturing. Journal of Manufacturing Technology Management, $23(3), \quad 351-369$. https://doi.org/10.1108/17410381211217416

Sharma, C., \& Mishra, R. K. (2015). International trade and performance of firms: Unraveling export, import, and productivity puzzle. Quarterly Review of Economics and Finance, 57, 61-74. https://doi.org/10.1016/j.qref.2015.02.001

Sjöholm, F. (1999). Productivity Growth in Indonesia: The Role of Regional Characteristics and Direct Foreign Investment. Economic Development and Cultural Change, 47(3), 559-584. https://doi.org/10.1086/452419 
Suyanto, Salim, R. A., \& Bloch, H. (2009). Does Foreign Direct Investment Lead to Productivity Spillovers? Firm-Level Evidence from Indonesia. World Development, 37(12), 1861-1876. https://doi.org/10.1016/j.worlddev.2009.05.009

Waldkirch, A., \& Ofosu, A. (2010). Foreign Presence, Spillovers, and Productivity: Evidence from Ghana. World Development, 38(8), 1114-1126. https://doi.org/10.1016/j.worlddev.2009.12.020

World Bank. (2019). Global economic risk and implications for Indonesia 